\title{
Identification of Resistance to Pseudocercosporella herpotrichoides in Triticum monococcum
}

\author{
M. M. Cadle and T. D. Murray, Department of Plant Pathology, and S. S. Jones, Department of Crop and Soil \\ Sciences, Washington State University, Pullman 99164-6430
}

\begin{abstract}
Cadle, M. M., Murray, T. D., and Jones, S. S. 1997. Identification of resistance to Pseudocercosporella herpotrichoides in Triticum monococcum. Plant Dis. 81:1181-1186.
\end{abstract}

Eyespot is an important disease of wheat in the United States Pacific Northwest. Genes Pchl, located on chromosome 7D, and Pch2, located on chromosome 7A, are the only known sources of eyespot resistance in hexaploid wheat. A core collection of Triticum monococcum, a close relative of the A-genome donor of bread wheat, consisting of 118 accessions from 26 countries was screened for resistance using a $\beta$-glucuronidase-transformed strain of the pathogen. Fiftytwo (44\%) accessions from 15 different countries were resistant. More than half of the accessions collected in Turkey (26 of 42) were resistant. Two accessions were more resistant than resistant cultivars Cappelle Desprez $(P c h 2)$ and Madsen $(P c h 1)$. Screening these accessions for the isozyme marker $E p$-A1b, which is linked with $P c h 2$ in hexaploid wheat, revealed variation but no association with resistance. These results indicate T. monococcum is a new source of resistance to Pseudocercosporella herpotrichoides that potentially contains more effective resistance to $P$. herpotrichoides than that conferred by either Pchl or Pch2.

Additional keywords: diversity index, genetic resistance, Triticum aestivum

Eyespot, a yield-limiting disease of wheat (Triticum aestivum L.) caused by Pseudocercosporella herpotrichoides (Fron) Deighton (teleomorph = Tapesia yallundae Wallwork \& Spooner), is capable of causing millions of dollars of damage to the wheat crop in the United States Pacific Northwest (USPNW) in years when it is severe (29). Planting resistant cultivars can save growers the cost of applying a fungicide, and minimize economic losses. Furthermore, strains of the pathogen resistant to commonly used benzimidazole fungicides are widespread, making utilization of disease resistant cultivars increasingly important $(21,32,29)$.

There are four known sources of resistance to eyespot. The most effective resistance gene $(P c h l)$ currently in use is derived from $T$. ventricosum Ces. (genomes $\mathrm{D}^{\mathrm{V}} \mathrm{D}^{\mathrm{V}} \mathrm{M}^{\mathrm{V}} \mathrm{M}^{\mathrm{V}}$ ), a distant wheat relative. This single gene, which is found in wheat line VPM-1, is located on chromosome 7D $(14,16)$. A second, less effective gene, $P c h 2$, is found in the cultivar Cappelle Desprez and is located on chromosome 7A $(6,25)$. Although the pedigree of Cappelle Desprez is known (8), the origin of Pch2 is not known. Two additional diploid wheat

Corresponding author: T. D. Murray

E-mail: tim_murray@wsu.edu

Plant Pathology New Series 0251

Accepted for publication 13 July 1997.

Publication no. D-1997-0825-04R

(C) 1997 The American Phytopathological Society species that confer resistance to eyespot are Dasypyrum villosum (L.) Candargy and T. tauschii (Coss.) Schmal. (31,38). Resistance in D. villosum is located on chromosome 4V (31); however, the chromosomal location of a resistance gene or genes in T. tauschii is unknown.

Pchl is the only eyespot resistance gene currently used in the USPNW, and cultivars containing this gene are grown on $34 \%$ of the total wheat acreage in Washington state (37). In contrast, Pch2 is not used, primarily because the resistance conferred by this gene is inadequate to prevent yield loss in most years $(8,30)$. Neither Pch1 nor Pch 2 confer complete resistance when used alone. Combining these genes in a single genotype, finding more effective alleles of these genes, or finding new, more effective genes would be of potential benefit to cultivar development programs.

Wild wheats are sources of disease resistance genes $(11,17,19,27)$, and it is possible to find variation for eyespot resistance among some of the wild populations (38). Einkorn wheats (T. urartu Thumanian ex Gandilyan, T. monococcum L. subsp. monococcum and T. m. boeoticum (Boiss.) Hayek) are all wild wheats (genomes AA); however, only T. urartu is considered to be the diploid A-genome donor of hexaploid wheat $(2 \mathrm{n}=6 \mathrm{x}=42$, AABBDD $)$ $(12,13,18,26)$. Unlike many diploid wheat relatives that are considered weeds, $T$. monococcum is cultivated in many parts of Europe and Asia for use as forage, bread making, and in pharmaceuticals. This species is known to contain resistance for other important wheat diseases and pests such as leaf rust, stripe rust, Karnal bunt, and Russian wheat aphid $(28,33)$. The presence of $P$ ch 2 on chromosome 7A in Cappelle Desprez suggests that the origin of this gene is an A-genome species; however, this is not known with certainty. Consequently, alleles conferring more effective resistance than $P$ ch 2 may exist if variation for this trait occurs among $T$. monococcum accessions.

Resistance to eyespot is associated with morphological and biochemical markers that can be useful in mapping or assessing diversity in wild populations $(22,25)$. Pchl is absolutely linked with the $E p-D 1 b$ band of the endopeptidase enzyme in VPM-1 and cultivars derived from this line. de la Peña et al. (6) speculated that this linkage is due to a nonrecombining fragment of $A e$. ventricosa chromatin containing Pchl inserted adjacent to $E p-D I b$. It is unknown if the endopeptidase locus is linked with eyespot resistance genes in Ae. ventricosa or other wild species, or if the absolute linkage in hexaploid wheat is an artifact of a translocation event. Regardless, breeders have used this close association with eyespot resistance in an application of markerbased selection resulting in the cultivars Hyak and Madsen $(1,2)$. A similar association, although not as tightly linked (about $15 \%$ recombination), has been found between $P c h 2$ and Ep-Alb (6). Red coleoptile color has also been associated with both Pch1 and Pch2, although other work has demonstrated that $P$ ch2 is unlinked to this trait $(25,6)$.

The purpose of this study was to determine if variation for resistance to eyespot exists in T. monococcum and, if so, the extent of this variation. Disease reaction was evaluated in a core collection of 118 accessions of $T$. monococcum collected from a wide geographic area. Screening for endopeptidase isozyme composition and coleoptile color were conducted to determine the association of these markers with resistance.

\section{MATERIALS AND METHODS}

Germ plasm. A core collection of 118 accessions of $T$. monococcum from 26 countries was selected by H. Bockleman, curator for the United States Department of Agriculture National Small Grains Collection (total T. monococcum collection = 235). Known resistant cultivars Cappelle Desprez and Madsen were included in the screening as resistant controls, and Chinese Spring was used as a susceptible control. 
Disease rating. Accessions were grown in a growth chamber in $1: 1$ (wt/wt) vermiculite:Thatuna silt loam in $5 \mathrm{~cm}$ peat pots in plastic flats at $12^{\circ} \mathrm{C}$, with $12 \mathrm{~h}$ light and 95 to $100 \%$ relative humidity (7). Five replicates containing two seeds of each accession were planted. Seedlings were inoculated with a $\beta$-glucuronidase (GUS)- transformed strain of $P$. herpotrichoides at the two-leaf stage as described by de la Peña and Murray (7), and grown under the same conditions for an additional 6 weeks. Disease reaction was evaluated after 6 weeks by measuring fluorescence of infected plant tissue extract after incubation with the GUS substrate 4-methylumbel- liferyl $\beta$-D-galactoside (MUG; 7). Disease was also scored visually on a 1 to 4 disease rating scale (37), where $1=$ no symptoms, 2 $=$ lesion on the first leaf sheath, $3=$ lesions on the first and second leaf sheaths, and $4=$ lesions covering the entire second leaf sheath and penetrating onto the third. Resistance was determined by comparison of $T$.

Table 1. Origin, coleoptile color, endopeptidase banding pattern (Ep), visual, and $\beta$-glucuronidase (GUS) disease score means of Triticum monococcum core collection

\begin{tabular}{|c|c|c|c|c|c|c|}
\hline \multirow[b]{2}{*}{ Accession } & \multirow[b]{2}{*}{ Cultivar } & \multirow[b]{2}{*}{ Origin } & \multirow[b]{2}{*}{ Coleoptile $^{y}$} & \multirow[b]{2}{*}{ Ep } & \multicolumn{2}{|c|}{ Disease score means } \\
\hline & & & & & Visual & $\mathbf{G U S}^{\mathbf{z}}$ \\
\hline CI 002433 & Einkorn & Germany & Green & 1 & 3.5 & $2.1 \mathrm{a}$ \\
\hline CI 013962 & & Oregon & Green & 2 & 3.0 & $1.9 \mathrm{a}$ \\
\hline CI 013963 & & Oregon & Green & 2 & 3.0 & $1.9 \mathrm{a}$ \\
\hline CI 013964 & & Oregon & Green & 2 & 2.0 & $1.7 \mathrm{ab}$ \\
\hline CI 014520 & & Canada & Green & 7 & 3.0 & $1.9 \mathrm{a}$ \\
\hline CI 017653 & Monococcum Mutant 3 & Washington & Green & 1 & 2.0 & $1.6 \mathrm{ab}$ \\
\hline CI 017655 & Monococcum Mutant 6 & Washington & Green & 1 & 2.8 & $1.9 \mathrm{a}$ \\
\hline CI 017657 & Monococcum Mutant 11 & Washington & Red & 2 & 3.0 & $1.9 \mathrm{a}$ \\
\hline PI 094741 & & Ukraine & Green & 3 & 1.0 & $1.7 \mathrm{ab}$ \\
\hline PI 094743 & & Russian Federation & Green & 1 & 1.3 & $1.8 \mathrm{ab}$ \\
\hline PI 119423 & & Turkey & Red & 2 & 1.0 & $1.6 \mathrm{ab}$ \\
\hline PI 119435 & & Turkey & Red & 2 & 1.5 & $1.7 \mathrm{ab}$ \\
\hline PI 167526 & & Turkey & Red & $\ldots$ & 2.8 & $1.7 \mathrm{ab}$ \\
\hline PI 167589 & & Turkey & Red & 2 & 2.8 & $1.8 \mathrm{ab}$ \\
\hline PI 167591 & & Turkey & Red & 2 & 3.0 & $1.7 \mathrm{ab}$ \\
\hline PI 167611 & & Turkey & Red & 2 & 1.8 & $1.8 \mathrm{ab}$ \\
\hline PI 167625 & & Turkey & Red & 2 & 3.3 & $1.8 \mathrm{ab}$ \\
\hline PI 167627 & & Turkey & Red & 1 & 3.5 & $1.9 \mathrm{a}$ \\
\hline PI 168803 & & Kansas & Green & 1 & 2.5 & $1.7 \mathrm{ab}$ \\
\hline PI 168804 & & Kansas & Green & 1 & 3.0 & $2.1 \mathrm{a}$ \\
\hline PI 168805 & & Kansas & $\ldots$ & 2 & 2.5 & $1.9 \mathrm{a}$ \\
\hline PI 168806 & Double Einkorn & Kansas & Green & 1 & 1.5 & $1.6 \mathrm{ab}$ \\
\hline PI 170196 & & Turkey & Red & $\ldots$ & 2.0 & $1.7 \mathrm{ab}$ \\
\hline PI 182461 & & Turkey & Green & 4 & 2.8 & $2 \mathrm{a}$ \\
\hline PI 190915 & & Spain & Green & 2 & 3.5 & $2 \mathrm{a}$ \\
\hline PI 190939 & & Spain & Green & 1 & 3.0 & $1.8 \mathrm{ab}$ \\
\hline PI 190940 & & Spain & Green & 1 & 2.8 & $1.9 \mathrm{a}$ \\
\hline PI 190942 & & Spain & Red & 2 & 1.5 & $1.6 \mathrm{ab}$ \\
\hline PI 221393 & & Yugoslavia & Red & 5 & 2.3 & $2 \mathrm{a}$ \\
\hline PI 221416 & & Yugoslavia & Red & 1 & 3.5 & $1.8 \mathrm{ab}$ \\
\hline PI 225164 & & Greece & Red & 2 & 2.5 & $1.9 \mathrm{a}$ \\
\hline PI 237659 & Einkorn & Kenya & Red & 2 & 2.5 & $1.8 \mathrm{ab}$ \\
\hline PI 264935 & & Greece & Green & $\ldots$ & 2.3 & $1.9 \mathrm{a}$ \\
\hline PI 265008 & & Bosnia/Herzegovina & Red & 1 & 2.8 & $2.1 \mathrm{a}$ \\
\hline PI 266844 & & United Kingdom & Red & 1 & 3.3 & $2.2 \mathrm{a}$ \\
\hline PI 272557 & & Hungary & Red & 5 & 4.0 & 2.4 \\
\hline PI 272561 & & Hungary & Red & 1 & 4.0 & $2.1 \mathrm{a}$ \\
\hline PI 277130 & & Uncertain & Red & $\ldots$ & 3.0 & $1.8 \mathrm{ab}$ \\
\hline PI 277133 & & Uncertain & Green & 1 & 2.5 & $2.3 \mathrm{a}$ \\
\hline PI 277138 & & Germany & Red & 5 & 4.0 & $2.1 \mathrm{a}$ \\
\hline PI 286068 & & Poland & Red & 7 & 1.0 & $1.7 \mathrm{ab}$ \\
\hline PI 289599 & & United Kingdom & Red & 2 & 2.3 & $1.7 \mathrm{ab}$ \\
\hline PI 289605 & & United Kingdom & Green & 6 & 4.0 & 2.5 \\
\hline PI 290508 & V.J. 388 & Hungary & Red & 2 & 2.5 & $1.9 \mathrm{a}$ \\
\hline PI 290509 & Blauer Kahler & Hungary & Green & 1 & 2.3 & $1.7 \mathrm{ab}$ \\
\hline PI 290511 & Spaniches Einkorn & Hungary & Green & 2 & 3.3 & $1.8 \mathrm{ab}$ \\
\hline PI 306542 & & Romania & Green & 5 & 3.5 & $2 \mathrm{a}$ \\
\hline PI 306543 & & Romania & Red & 1 & 3.8 & $2 \mathrm{a}$ \\
\hline PI 306547 & & Romania & Red & 1 & 3.5 & $2 \mathrm{a}$ \\
\hline PI 326217 & & Uncertain & Red & 6 & 4.0 & 2.5 \\
\hline PI 330551 & & United Kingdom & Green & 1 & 2.8 & $1.9 \mathrm{a}$ \\
\hline PI 343181 & Macedonicum & Chile & Red & 7 & 1.5 & $1.7 \mathrm{ab}$ \\
\hline PI 345133 & & Yugoslavia & Red & 2 & 3.0 & $2.3 \mathrm{a}$ \\
\hline PI 345186 & & Yugoslavia & Red & 2 & 2.0 & $1.2 \mathrm{abc}$ \\
\hline PI 345242 & & Macedonia & Red & 7 & 2.5 & $1.9 \mathrm{a}$ \\
\hline PI 349049 & & Armenia & Green & 6 & 3.5 & $2.2 \mathrm{a}$ \\
\hline PI 352475 & & Germany & Green & 5 & 4.0 & 2.5 \\
\hline PI 352483 & & Spain & Green & 2 & 1.8 & $1.7 \mathrm{ab}$ \\
\hline
\end{tabular}

y ... indicates no data.

${ }^{\mathrm{z}}$ Least significant difference $=0.4, \alpha=0.05, \mathrm{a}=$ significantly different from Chinese Spring, $\mathrm{b}=$ significantly different from Cappelle Desprez, $\mathrm{c}=$ significantly different from Madsen. 
monococcum log-transformed GUS scores with the controls. To confirm resistance, a second experiment was carried out under the same conditions with 52 accessions determined to be more resistant than Cappelle Desprez in the first experiment. In addition, coleoptile color was noted at emergence in all replicates in each experiment.
Endopeptidase determination. A single seed of each T. monococcum accession was sown in vermiculite in $5 \mathrm{~cm}$ pots, grown to the one-leaf stage, and placed in a growth chamber $\left(4^{\circ} \mathrm{C}, 12 \mathrm{~h}\right.$ light $)$ for 6 weeks for vernalization. One week before removal from the growth chamber, the second youngest leaf of each accession was collected and placed on ice. Each leaf was passed through a rotary sap extractor with $50 \mu$ buffer (25 mM glycylglycine, $\mathrm{pH}$ 7.4) and kept on ice until all samples were processed. A $10 \times$ loading dye containing $20 \%$ sucrose and $0.25 \%$ xylene cyanole was added, and the samples briefly centrifuged prior to loading. Samples were

Table 1. (continued from previous page)

\begin{tabular}{|c|c|c|c|c|c|c|}
\hline \multirow[b]{2}{*}{ Accession } & \multirow[b]{2}{*}{ Cultivar } & \multirow[b]{2}{*}{ Origin } & \multirow[b]{2}{*}{ Coleoptiley } & \multirow[b]{2}{*}{ Ep } & \multicolumn{2}{|c|}{ Disease score means } \\
\hline & & & & & Visual & $\mathbf{G U S}^{\mathbf{z}}$ \\
\hline PI 352484 & & Yugoslavia & Red & 7 & 3.5 & $2 \mathrm{a}$ \\
\hline PI 355517 & & Turkey & Green & 5 & 4.0 & 2.4 \\
\hline PI 355519 & & Iran & Red & 2 & 3.8 & $2.2 \mathrm{a}$ \\
\hline PI 355521 & & Turkey & Red & 1 & 3.3 & $2.1 \mathrm{a}$ \\
\hline PI 355522 & & Germany & Red & 2 & 4.0 & $2.2 \mathrm{a}$ \\
\hline PI 355523 & & Turkey & Red & 2 & 3.0 & $2 \mathrm{a}$ \\
\hline PI 355526 & & Belgium & Green & 2 & 2.8 & $1.9 \mathrm{a}$ \\
\hline PI 355529 & & Belgium & Green & 1 & 3.3 & $1.9 \mathrm{a}$ \\
\hline PI 355530 & & Spain & Red & 2 & 2.8 & $1.9 \mathrm{a}$ \\
\hline PI 355531 & & Belgium & Red & 2 & 1.5 & $1.6 \mathrm{ab}$ \\
\hline PI 355536 & JE 28 & Italy & Red & 1 & 1.0 & $1.4 \mathrm{abc}$ \\
\hline PI 355543 & & Germany & Green & 5 & 3.0 & $1.8 \mathrm{ab}$ \\
\hline PI 355544 & & Germany & Red & 1 & 2.3 & $1.8 \mathrm{ab}$ \\
\hline PI 355547 & & Austria & Red & 1 & 3.3 & $2 \mathrm{a}$ \\
\hline PI 355548 & & Austria & Red & 1 & 3.0 & $2 \mathrm{a}$ \\
\hline PI 355549 & & Austria & Red & 1 & 3.5 & $2 \mathrm{a}$ \\
\hline PI 362610 & & Macedonia & Red & $\ldots$ & 3.0 & $2.1 \mathrm{a}$ \\
\hline PI 377666 & & Yugoslavia & Red & 2 & 3.8 & $2.1 \mathrm{a}$ \\
\hline PI 377667 & & Yugoslavia & Red & 2 & 3.0 & $1.9 \mathrm{a}$ \\
\hline PI 377669 & & Yugoslavia & Green & 2 & 1.8 & $1.7 \mathrm{ab}$ \\
\hline PI 377670 & & Yugoslavia & Green & 2 & 2.3 & $1.9 \mathrm{a}$ \\
\hline PI 377671 & & Yugoslavia & Red & 2 & 3.0 & $2 \mathrm{a}$ \\
\hline PI 393496 & Einkorn & Israel & Green & 1 & 3.0 & $1.9 \mathrm{a}$ \\
\hline PI 418582 & & Georgia & Green & 6 & 3.8 & $2.1 \mathrm{a}$ \\
\hline PI 427927 & & Iraq & Red & 1 & 3.0 & $2.1 \mathrm{a}$ \\
\hline PI 427959 & & Iraq & Green & 7 & 1.5 & $1.7 \mathrm{ab}$ \\
\hline PI 428149 & & Sweden & Red & 2 & 2.0 & $2.1 \mathrm{a}$ \\
\hline PI 428151 & & Italy & Green & 6 & 4.0 & $2.3 \mathrm{a}$ \\
\hline PI 428152 & & Belgium & Red & 2 & 2.5 & $1.9 \mathrm{a}$ \\
\hline PI 428153 & & California & Green & 7 & 1.5 & $1.7 \mathrm{ab}$ \\
\hline PI 428158 & & United Kingdom & Red & 2 & 3.5 & $1.9 \mathrm{a}$ \\
\hline PI 428160 & & Turkey & Red & 2 & 2.0 & $1.8 \mathrm{ab}$ \\
\hline PI 428161 & & Turkey & Red & 7 & 3.3 & $1.8 \mathrm{ab}$ \\
\hline PI 428162 & & Turkey & Red & 2 & 2.8 & $1.8 \mathrm{ab}$ \\
\hline PI 428163 & & Turkey & Red & 2 & 2.3 & $1.7 \mathrm{ab}$ \\
\hline PI 428164 & & Turkey & Red & 2 & 2.5 & $1.9 \mathrm{a}$ \\
\hline PI 428165 & & Turkey & Red & 2 & 3.0 & $2.1 \mathrm{a}$ \\
\hline PI 428166 & & Turkey & Red & 2 & 3.3 & $1.9 \mathrm{a}$ \\
\hline PI 428168 & & Turkey & Red & 6 & 3.3 & $2.3 \mathrm{a}$ \\
\hline PI 428169 & & Turkey & Red & 1 & 3.0 & $1.8 \mathrm{ab}$ \\
\hline PI 428171 & & Turkey & Red & 7 & 2.5 & $1.9 \mathrm{a}$ \\
\hline PI 428172 & & Turkey & Red & 2 & 2.3 & $1.7 \mathrm{ab}$ \\
\hline PI 428173 & & Turkey & Red & 2 & 3.0 & $1.7 \mathrm{ab}$ \\
\hline PI 428175 & & Turkey & Red & 1 & 2.0 & $1.7 \mathrm{ab}$ \\
\hline PI 428176 & & Turkey & Green & 2 & 2.0 & $1.8 \mathrm{ab}$ \\
\hline PI 538721 & & Turkey & Red & 1 & 3.8 & $2.1 \mathrm{a}$ \\
\hline PI 538722 & & Turkey & Red & 2 & 3.0 & $1.7 \mathrm{ab}$ \\
\hline PI 554525 & & Turkey & Red & $\ldots$ & 3.0 & $2 \mathrm{a}$ \\
\hline PI 554529 & & Turkey & Red & $\ldots$ & 2.3 & $1.7 \mathrm{ab}$ \\
\hline PI 554596 & & Turkey & Red & 2 & 1.8 & $1.7 \mathrm{ab}$ \\
\hline PI 560727 & & Turkey & Red & 1 & 2.8 & $2 \mathrm{a}$ \\
\hline PI 573520 & & Turkey & Red & 7 & 2.5 & $2.1 \mathrm{a}$ \\
\hline PI 573521 & & Turkey & Red & $\ldots$ & 3.8 & $1.8 \mathrm{ab}$ \\
\hline PI 573523 & & Turkey & Red & 2 & 2.5 & $1.7 \mathrm{ab}$ \\
\hline PI 573524 & & Turkey & Red & $\ldots$ & 3.5 & $1.8 \mathrm{ab}$ \\
\hline PI 573525 & & Turkey & Red & 1 & 3.5 & $1.8 \mathrm{ab}$ \\
\hline PI 573526 & & Turkey & Red & 1 & 3.8 & $2 \mathrm{a}$ \\
\hline PI 573527 & & Turkey & Red & 1 & 3.3 & $1.8 \mathrm{ab}$ \\
\hline PI 573528 & & Turkey & Red & 1 & 2.8 & $1.8 \mathrm{ab}$ \\
\hline PI 573529 & & Turkey & Red & 1 & 3.5 & $1.8 \mathrm{ab}$ \\
\hline Madsen & & & & & 1.8 & 1.8 \\
\hline Cappelle Desprez & & & & & 3.0 & 2.1 \\
\hline Chinese Spring & & & & & 3.8 & 2.7 \\
\hline
\end{tabular}


loaded onto a vertical polyacrylamide gel apparatus using a lithium-borate buffer system (4\% stacking gel, 10\% running gel, $16 \mathrm{mM}$ boric acid $\mathrm{pH} 8.3,3 \mathrm{mM} \mathrm{LiOH}, 37$ $\mathrm{mM}$ Tris, $5 \mathrm{mM}$ citric acid) and run at 35 $\mathrm{mA} /$ gel constant current for $3.5 \mathrm{~h}$. After running, gels were trimmed to approximately $5 \mathrm{~cm}$ above the dye front and placed in staining solution $(100 \mathrm{mM}$ Trismaleate $\mathrm{pH} 3.7,38 \mathrm{mM} \mathrm{NaOH}, 1 \mathrm{mM} \alpha-$ $N$-benzoyl-DL-arginine- $\beta$-naphthylamide $\cdot \mathrm{HCl}$, $0.8 \mathrm{mg} / \mathrm{ml}$ Fast Black $\mathrm{K}$ salts) in the dark for 1 to $2 \mathrm{~h}$ to visualize the endopeptidase bands. Controls were Chinese Spring and Cappelle Desprez.

Statistical analysis. Analysis of variance was conducted on the data from each experiment using SAS statistical analysis software (SAS Institute, Cary, NC). Fisher's least significant difference (LSD, $P=0.05$ ) was used to separate means.

\section{RESULTS AND DISCUSSION}

Of 118 T. monococcum accessions, 114 possessed GUS scores significantly lower than the susceptible check (Chinese Spring), which corresponded to reduced colonization by the fungus. Fifty-two accessions were significantly lower than Cappelle Desprez (mean $=2.1)$ and 2 were significantly lower than Madsen (mean = 1.8; Table 1). The overall mean of the population, excluding the controls, was 1.9 (Table 2). It should be noted that the potential source species for $P \operatorname{ch} 2$ is, on average, more resistant than the common wheat carrying it.

The second experiment was conducted on the 52 accessions that were more resistant than Cappelle Desprez in the first experiment. This was done to confirm that these lines were resistant and not escapes. All accessions screened in the second experiment were confirmed to be resistant (Fig. 1).

Among countries contributing more than one accession to the collection, the highest frequency of resistant accessions was

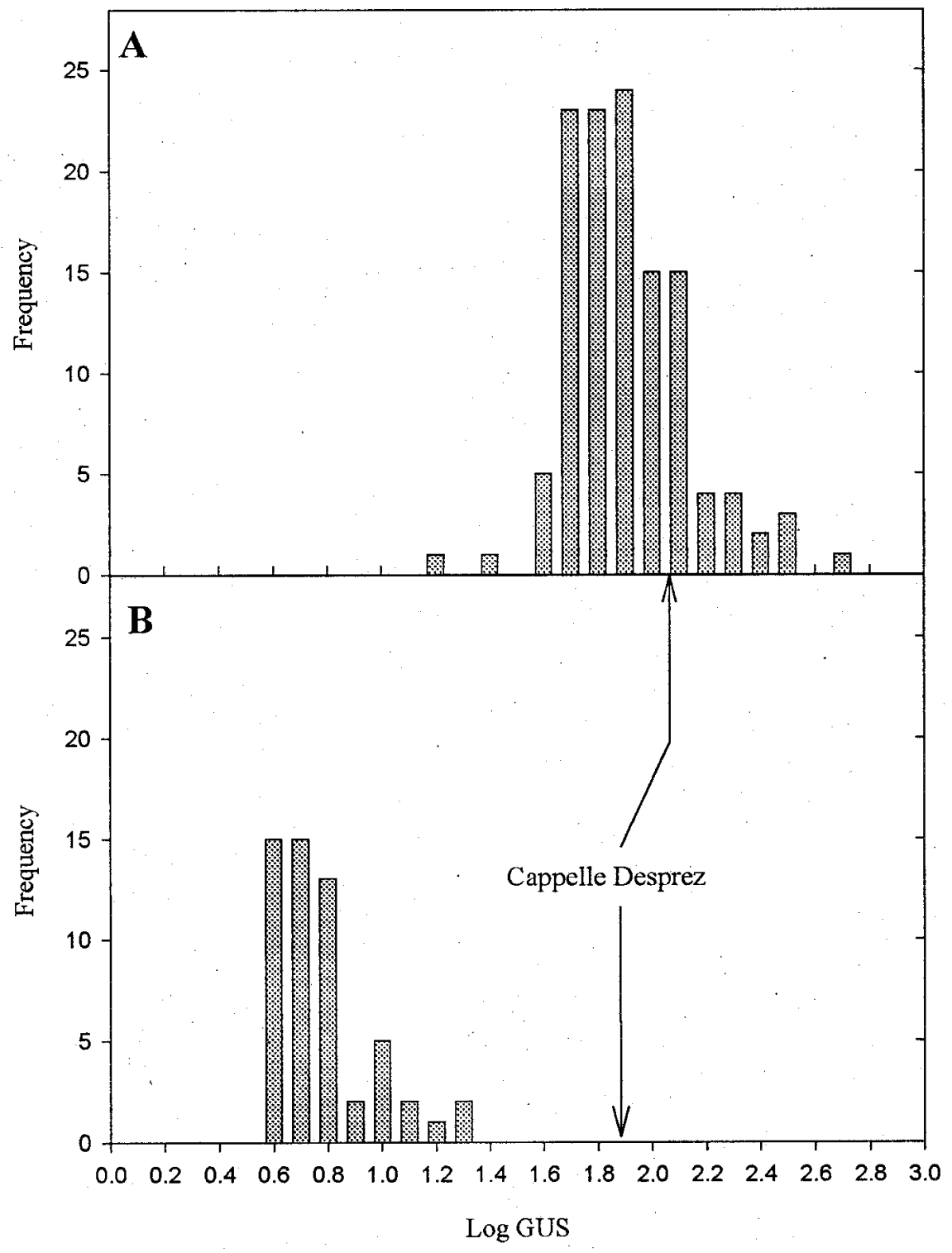

Fig. 1. Frequency distributions for (A) the first eyespot resistance experiment, including the entire Triticum monococcum core collection, and (B) the second eyespot experiment, containing only accessions classified as resistant by the first experiment. The arrows indicate the $\log -\beta$-glucuronidase score of Cappelle Desprez in each experiment.

Table 2. Geographic distribution of Triticum monococcum endopeptidase isozyme classes and eyespot resistance

\begin{tabular}{|c|c|c|c|c|c|}
\hline \multirow[b]{2}{*}{ Origin } & \multirow[b]{2}{*}{ Accessions } & \multirow[b]{2}{*}{ Endopeptidase class } & \multirow[b]{2}{*}{ Mean } & \multicolumn{2}{|c|}{$\begin{array}{l}\text { Accessions with GUS }{ }^{\mathrm{z}} \text { activity lower } \\
\text { (more resistant) than check }\end{array}$} \\
\hline & & & & Cappelle Desprez & Madsen \\
\hline Chile & 1 & 7 & 1.7 & 1 & 0 \\
\hline Poland & 1 & 7 & 1.7 & 1 & 0 \\
\hline Russian Federation & 1 & 1 & 1.8 & 1 & 0 \\
\hline Ukraine & 1 & 3 & 1.7 & 1 & 0 \\
\hline Italy & 2 & 1,6 & 1.9 & 1 & 1 \\
\hline Iraq & 3 & $1,2,7$ & 2 & 1 & 0 \\
\hline Belgium & 4 & 1,2 & 1.9 & 1 & 0 \\
\hline Hungary & 5 & $1,2,5$ & 2 & 2 & 0 \\
\hline United Kingdom & 5 & $1,2,6$ & 2 & 1 & 0 \\
\hline Germany & 6 & $1,2,5$ & 1.9 & 2 & 0 \\
\hline Spain & 6 & 1,2 & 1.9 & 3 & 0 \\
\hline Yugoslavia & 10 & $1,2,5,7$ & 1.8 & 3 & 1 \\
\hline USA & 11 & $1,2,7$ & 1.8 & 5 & 0 \\
\hline Turkey & 42 & $1,2,4,5,6$ & 1.9 & 26 & 0 \\
\hline Others ( 12 countries) & 17 & $1,2,5,6,7$ & 2 & 0 & 0 \\
\hline Overall & 118 & & 1.9 & 52 & 2 \\
\hline
\end{tabular}

${ }^{\mathrm{z}}$ GUS $=\beta$-glucuronidase. 
among wheats from Turkey. Of 42 accessions from Turkey, 26 (62\%) were significantly more resistant that Cappelle Desprez, whereas none was more resistant than Madsen based on GUS scores. Individual accessions from Italy and Yugoslavia had the lowest GUS scores, indicating that they were more resistant. One accession from each of these countries was more resistant than Madsen (Table 2).

No correlation was found between coleoptile color and eyespot resistance. This corresponds with linkage data reported by de la Peña et al. (6). $R c l$, which conditions red coleoptile color, was found on the short arm of chromosome 7A, whereas Pch2 is on the long arm. The presence of both genes on the same chromosome may result in the two loci segregating apparently nonindependently in populations. However, the loose linkage is of little value in screening for resistance to eyespot.

Seven different endopeptidase banding patterns were identified in the screening population, ranging from 2 to 6 bands per accession (Table 1, Fig. 2). However, no association with resistance was identified. None of the banding patterns was in common with the Ep-Alb band found in Cappelle Desprez. Only one accession (PI182461) was found with banding pattern 4 (Fig. 2), and it was determined to be hexaploid by chromosome counts.

The technique used here for endopeptidase isozyme electrophoresis is a significant modification of techniques described by Koebner et al. (23), involving isoelec-

Table 3. Frequency of endopeptidase banding patterns in Triticum monococcum screening population

\begin{tabular}{lrc}
\hline $\boldsymbol{E p}$ - $\boldsymbol{A 1 \boldsymbol { b }}$ & $\#$ & Frequency $^{\mathbf{z}}$ \\
\hline 1 & 37 & 0.3394 \\
2 & 47 & 0.4312 \\
3 & 1 & 0.0092 \\
4 & 1 & 0.0092 \\
5 & 7 & 0.0642 \\
6 & 6 & 0.0550 \\
7 & 10 & 0.0917 \\
Total & 109 & \\
\hline
\end{tabular}

${ }^{\mathrm{z}}$ Shannon's diversity index $(\mathrm{H})=1.371$. tric focusing, and Vahl et al. (35), that requires bulking five individuals for detection. The present system reduces the cost of this assay and allows detection of isozyme bands in individual plants. This technique may be of value for breeders or others making selections on large numbers of single early generation lines.

An estimate of diversity for the collection was calculated using Shannon's diversity index for isozyme data, $\mathrm{H}=-\left(\sum \mathrm{p}_{\mathrm{i}} \mathrm{l} n\right.$ $\mathrm{p}_{\mathrm{i}}$ ) (Table 3 ; 15). The resultant value of $\mathrm{H}$ $=1.371$ indicates a moderate level of diversity. This result is consistent with the low levels of diversity in T. monococcum var. boeoticum enzyme populations found by Smith-Huerta et al. (34) using Nei's Identity index (NI) and among random amplified polymorphic DNA (RAPD) markers used by Vierling and Nguyen (36), who used Jaccard's similarity coefficients in collections of T. urartu and T. monococcum. Smith-Huerta et al. (34) found values of NI for T. monococcum ranging from 0.894 to 1.000 for 12 isozyme systems, whereas Vierling and Nguyen (36) calculated a range of 0.67 to 0.81 for Jaccard's coefficient using 60 RAPD markers. Each of the studies presented used a different index for diversity or similarity, as well as the use of only a single marker in the present study; therefore, none of the values can be compared directly. However, each study either indicates very high similarities or moderate to low levels of diversity within T. monococcum.

Comparisons between diploid wild wheat relatives and hexaploid wheats for effectiveness of resistance and genetic control should not be made because of the potential epistatic effects with other loci in the genomes of hexaploid wheat. The resistant phenotype observed in hexaploid wheat is potentially affected by other loci in all three ancestral genomes, including two additional homoeoloci. In a diploid wheat such as T. monococcum, epistatic effects occur only within the single genome present and there are no other homoeoloci. The effectiveness of $T$. monococcum resistance gene(s) when introgressed into the hexaploid milieu is unknown.

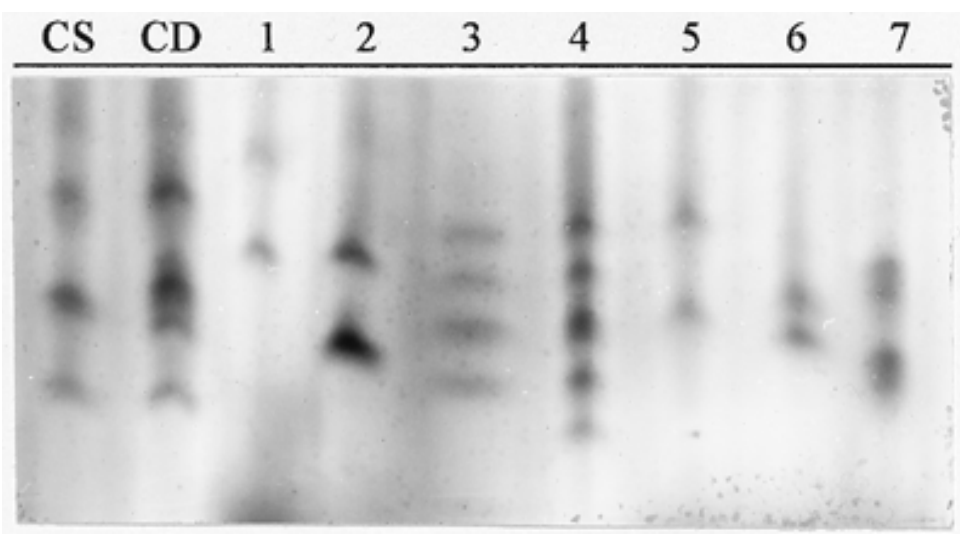

Fig. 2. Triticum monococcum endopeptidase (Ep-1a) banding patterns and scoring scheme.
Furthermore, to determine if resistance in T. monococcum is allelic to Pch2, crosses would have to be made between Cappelle Desprez and T. monococcum. Although it is possible to cross T. monococcum with hexaploid wheat, the $\mathrm{F}_{1}$ plants exhibit low fertility, and any progeny from such crosses would have unstable chromosome constitutions. Consequently, genetic studies on resistance using populations derived from hexaploid $\times$ diploid crosses would be of little use, due to the confounding effects of reduced fecundity and chromosome loss. The number of genes present in $T$. monococcum and their allelism can be determined in the diploid species; however, the most useful genetic analyses with Pch2 would be at the hexaploid level.

Transfer of disease resistance genes against leaf rust, Karnal bunt, and Russian wheat aphid from $T$. monococcum to hexaploid wheat has been successful without the use of embryo rescue or culturing techniques $(5,28,33)$. Additionally, resistance genes that have been transferred from this species to common wheat have retained their effectiveness at the hexaploid level $(28,33)$. This is in contrast to studies by Lange and Jochemsen (24) and Kema et al. (20), for example, that show reduced resistance of synthetic hexaploids derived from the wild species T. tauschii (genomes DD).

The fact that resistance conferred by $P c h 2$ is less effective than that conferred by Pchl has led to less emphasis on utilization of the former resistance gene $(9,10,30)$. However, there may be alleles at this locus in T. monococcum that are more effective. In the present core collection, we found diploids with apparently greater resistance than that conferred by Pch2 and also greater than $P c h 1$. The relative ease with which amphiploids between $T$. monococcum and tetraploid and hexaploid wheats can be made makes this a valuable new source of resistance to $P$. herpotrichoides. The addition of a second highly effective resistance gene, and the potential for gene pyramiding in adapted wheats, will be a significant advancement for cultivar improvement.

\section{ACKNOWLEDGMENTS}

We thank the Washington State Wheat Commission for financial support, and Dr. H. Bockelman, curator of the USDA-ARS National Plant Germplasm System, for the core collection of $T$. monococcum used in this study.

\section{LITERATURE CITED}

1. Allan, R. E., Peterson, C. J., Rubenthaler, G. L., Line, R. F., and Roberts, D. E. 1989. Registration of 'Madsen' wheat. Crop Sci. 29: 1575-1576.

2. Allan, R. E., Peterson, C. J., Rubenthaler, G. L., Line, R. F., and Roberts, D. E. 1990. Registration of 'Hyak' wheat. Crop Sci. 30:234.

3. Bruehl, G. W., Nelson, W. L., Koehler, F., and Vogel, O. A. 1968. Experiments with Cercosporella foot rot (strawbreaker) disease of winter wheat. Wash. Agric. Exp. 
Stn. Bull. 694.

4. Chao, S., Sharp, P. J., Worland, A. J., Warham, E. J., Loebner, R. M. D., and Gale, M. D. 1989. RFLP-based genetic maps of wheat homologous group 7 chromosomes. Theor. Appl. Genet. 78:495-504.

5. Cox, T. S., Harrell, L. G., Chen, P., and Gill, B. S. 1991. Reproductive behavior of hexaploid/diploid wheat hybrids. Plant Breeding 107:105-118.

6. de la Peña, R. C., Murray, T. D., and Jones, S. S. 1996. Linkage relations among eyespot resistance gene $P c h 2$, endopeptidase $E p-A 1 b$, and RFLP marker Xpsr121 on chromosome 7A of wheat. Plant Breeding 115:273-275.

7. de la Peña, R. C, and Murray, T. D. 1994. Identifying wheat genotypes resistant to eyespot disease with a $\beta$-glucuronidase-transformed strain of Pseudocercosporella herpotrichoides. Phytopathology 84:972-977.

8. Doussinault, G. 1970. Problèmes posés par l'amélioration de la résistance du blé tendre vis-a-vis du piétin-verse Cercosporella herpotrichoides Fron. Ann. Amélior. Plant. (Paris) 20:433-452.

9. Doussinault, G. 1973. Comportement de 12 variétés de blé tendre vis-a-vis du piétin-verse (Cercosporella herpotrichoides Fron). Conséquenses pour la sélection. Ann. Amélior. Plant. (Paris) 23:333-346.

10. Doussinault, G, Koller, J, and Touvin, $\mathrm{H}$. 1974. Utilisation de géniteurs VPM 1 dans l'amélioration de l'état sanitaire du blé tendre. Ann. Amélior. Plant. (Paris) 24:215-241.

11. Dvorák, J., and McGuire P. E. 1991. Triticeae, the gene pool for wheat breeding. Pages 3-8 in: Genome mapping of wheat and related species: Proceedings of a public workshop. Rep. 7. Univ. Calif. Genet. Resour. Program, Davis, CA.

12. Dvorák, J., di Terlizzi, P., Zhang, H-B., and Resta, P. 1993. The evolution of polyploid wheats: identification of the A-genome donor species. Genome 36:21-31.

13. Dvorák, J., and Zhang, H-B. 1992. Reconstruction of the phylogeny of the genus Triticum from variation in repeated nucleotide sequences. Theor. Appl. Genet. 84:419-429.

14. Gale, M. D., Scott, P. R., Law, C. N., Ainsworth, C. C., Hollins, T. W., and Worland, A. J. 1984. An $\alpha$-amylase gene from $A e$ gilops ventricosa transferred to breadwheat together with a factor for eyespot resistance. Heredity 52:431-435.

15. Groth, J. V., and Roelfs, A. P. 1987. The concept and measurement of phenotypic diversity in Puccinia graminis on wheat. Phytopathology 77:1395-1399.

16. Jahier, J., Doussinault, G., Dosba, F., and Bourgeois, F. 1978. Monosomic analysis of resistance to eyespot in the variety 'Roazon.' Pages 437-440 in: Proc. Int. Wheat Genet. Symp., New Delhi, India.

17. Jiang, J., Friebe, B., and Gill, B. S. 1994. Recent advances in alien gene transfer in wheat. Euphytica 73:199-212.

18. Jiang, J., and Gill, B. S. 1994. New 18S.26S ribosomal RNA gene loci: chromosomal landmarks for the evolution of polyploid wheats. Chromosoma (Berl) 103:179-185.

19. Jones, S. S., Murray, T. D., and Allan, R. E. 1995. Use of alien genes for the development of disease resistance in wheat. Annu. Rev. Phytopathol. 33:429-443.

20. Kema, E. G. J., Lange, W., and Silfhout, C. H. van. 1995. Differential suppression of stripe rust resistance in synthetic wheat hexaploids derived from Triticum turgidum subsp. dicoccoides and Aegilops squarrosa. Phytopathology 85:425-429.

21. King, J. E., and M. J. Griffin. 1985. Survey of benomyl resistance in Pseudocercosporella herpotrichoides in winter wheat and barley in England and Wales in 1983. Plant Pathol. 34:272-283.

22. Koebner, R. M. D., and Martin, P. K. 1990. Association of eyespot resistance in wheat cv. 'Cappelle Desprez' with endopeptidase profile. Plant Breed. 104:312-317.

23. Koebner, R. M. D., Miller, T. E., Snape, J. W., and Law, C. N. 1987. Wheat endopeptidase: genetic control, polymorphism, intrachromosomal gene location, and alien variation. Genome 30:186-192.

24. Lange, W., and Jochemsen, G. 1992. Use of the gene pools of Triticum turgidum ssp. dicoccoides and Aegilops squarrosa for the breeding of common wheat ( $T$. aestivum), through chromosome-doubled hybrids II. Morphology and meiosis of the amphiploids. Euphytica 59:213-220.

25. Law, C. N., Scott, P. R., Worland, A. J., and Hollins, T. W. 1976. The inheritance of resistance to eyespot (Cercosporella herpotrichoides) in wheat. Genet. Res. 25:73-79.

26. Le Corre, V., and Bernard, M. 1995. Assessment of the type and degree of restriction fragment length polymorphism (RFLP) in diploid species of the genus Triticum. Theor. Appl. Genet. 90:1063-1067.

27. McIntosh, R. A. 1991. Alien sources of disease resistance in bread wheats. Pages 320-
332 in: Proc. Dr. H. Kihara Memorial Int. Symp. Cytoplasmic Eng. Wheat. Nuclear and Organellar Genomes of Wheat Species, T. Sasakuma and T. Kinoshita, eds. Yokahoma, Japan.

28. Multani, D. S., Dhaliwal, H. S., Singh, P., and Gill, K. S. 1988. Synthetic amphiploids of wheat as a source of resistance to Karnal bunt (Neovossia indica). Plant Breeding. 101:122125.

29. Murray, T. D. 1996. Resistance to benzimidazole fungicides in the cereal eyespot pathogen, Pseudocercosporella herpotrichoides, in the Pacific Northwest 1984 to 1990. Plant Dis. 80:19-23.

30. Murray, T. D., and Bruehl, G. W. 1983. Role of the hypodermis and secondary cell wall hickening in basal stem internodes in resistance to strawbreaker foot rot in winter wheat Phytopathology 73:261-268.

31. Murray, T. D., de la Peña, R. C., Yildirim, A., and Jones, S. S. 1994. A new source of resistance to Pseudocercosporella herpotrichoides, cause of eyespot disease of wheat, located on chromosome 4V of Dasypyrum villosum. Plant Breeding 113:281-286.

32. Murray, T. D., Smiley, R. W., and Uddin, W. 1990. Resistance to benzimidazole fungicides in Pseudocercosporella herpotrichoides in Washington and Oregon. (Abstr.) Phytopathology 80:1041

33. Potgieter, G. F., Marais, G. F., and Du Toit, F. 1991. The transfer of resistance to the Russian wheat aphid from Triticum monococcum L. to common wheat. Plant Breeding 106:284-292.

34. Smith-Huerta, N. L., Huerta, A. J., Barnhart, D., and Waines, J. G. 1989. Genetic diversity in wild diploid wheats Triticum monococcum var. boeoticum and T. urartu (Poaceae). Theor. Appl. Genet. 78:260-264.

35. Vahl, U., Muller, G., Thiele, A., and Thiele, M. 1987. Multiple endopeptidasen als biochemische marker für die resistenz von winterweizen gegenüber Pseudocercosporella herpotrichoides (Fron) Deighton. Plant Breeding 99:218-225.

36. Vierling, R. A., and Nguyen, H. T. 1992. Use of RAPD markers to determine the genetic diversity of diploid, wheat genotypes. Theor. Appl. Genet. 84:835-838.

37. Washington Agricultural Statistics Service. 1996. Wash. Agric. Statistics

38. Yildirim, A., Jones, S. S., Murray, T. D., Cox, T. S., and Line, R. F. 1995. Resistance to stripe rust and eyespot diseases of wheat in Triticum tauschii. Plant Dis. 79:1230-1236. 